Int. J. Odontostomat.,

7(3):471-473, 2013.

\title{
Bilateral Two-rooted Mandibular Canines in the Same Individual: a Case Report
}

\author{
Caninos Mandibulares Birradiculares Bilaterales en \\ el Mismo Individuo: Presentación de un Caso
}

Ramón Fuentes \& Eduardo Borie

FUENTES, R. \& BORIE, E. Bilateral two-rooted mandibular canines in the same individual: a case report. Int. J. Odontostomat., 7(3):471-473, 2013.

ABSTRACT: The normal anatomy of canines teeth comprises one root and one large canal centered through its axis; however some canines may present two roots and two canals. Thus, the knowledge of normal root canal anatomy and their variations is essential to minimize the possibility of occurrence of accidents during the development of dental treatments. In this report we describe a case of bilateral mandibular canines with two roots and two canals found radiographically in the same individual.

KEY WORDS: dental morphology, mandibular canine, root anatomy.

\section{INTRODUCTION}

Tooth development results of several interactions between oral epithelium and underlying mesenchymatic tissue during odontogenesis (Fuentes \& Oporto, 2009; Borie et al., 2010). Dental anomalies can results from many factors, including genetic and environmental ones. Although defects in certain genes have the highest incidence, etiological events in prenatal and postnatal periods have also been blamed for anomalies in tooth dimension, morphology, position, number, and structure (Basdra et al., 2000; Uslu et al., 2009).

Morphological variations occur by the interaction of abnormal tissue during the specific stages of tooth development. According to the period when this condition happens, the tooth could show an abnormal development and / or eruption, ectopic or some anatomical variation (Oporto et al., 2010). There are various theories explaining the existence of abnormal number of roots (greater than normal), including hyperactivity of the Hertwig's epithelial root sheath (Holtzman, 1997) and a pathological degeneration in the same area, producing an invagination from the dental papilla forming an accessory root (Roig \& Morelló, 2006).
Generally, the basic anatomy of canines comprises one root and one large canal centered through its axis, but approximately $15 \%$ of the case reported the presence of two canals in the mandibular canine; more rare is the report of the presence of two different angulated roots (Andrei et al., 2011), observing the prevalence reported in the literature between $1.7 \%$ (Pécora et al., 1993) to 5\% (Ouellet, 1995).

Therefore, the aim of this article is to present a case of bilateral mandibular two-rooted mandibular canines with two canals in a patient without underlying disease.

\section{CASE REPORT}

A 44-year-old Chilean female individual came to dental control for a routine examination. The extraoral examination showed no abnormalities, and the intraoral investigation revealed the presence of caries in some teeth, not showing any signs of periodontal disease. Among the complementary tests that were requested, a panoramic radiograph was taken with 
plaster casts for the maxilla and mandible. In panoramic radiograph the both canines in the mandible showed two roots and two canals (Fig. 1). Subsequently, a periapical radiograph of both mandibular canines was taken to check de initial diagnosis (Fig. 2). During anamnesis, the patient reported no history for systemic or syndrome diseases.

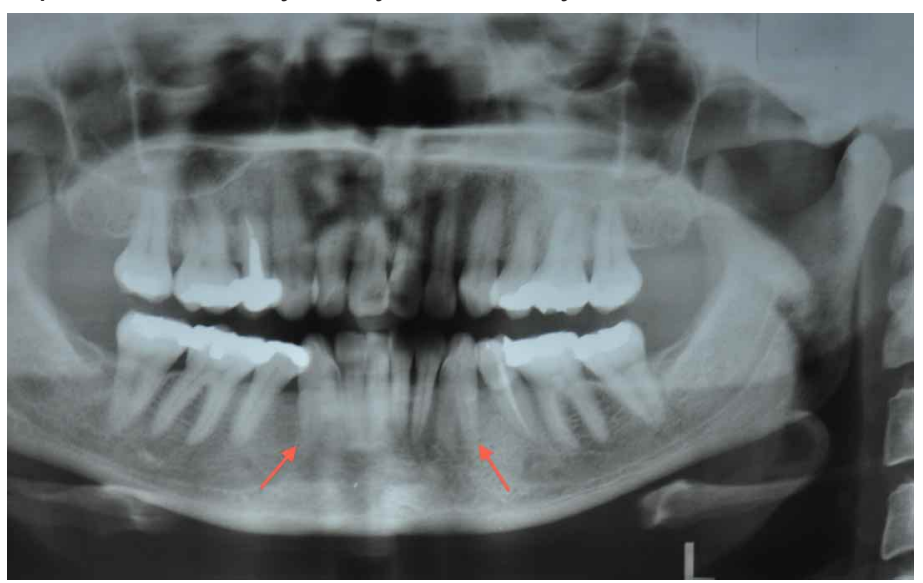

Fig. 1. Panoramic radiograph of the individuals with bilateral tworooted mandibular canines (arrows).
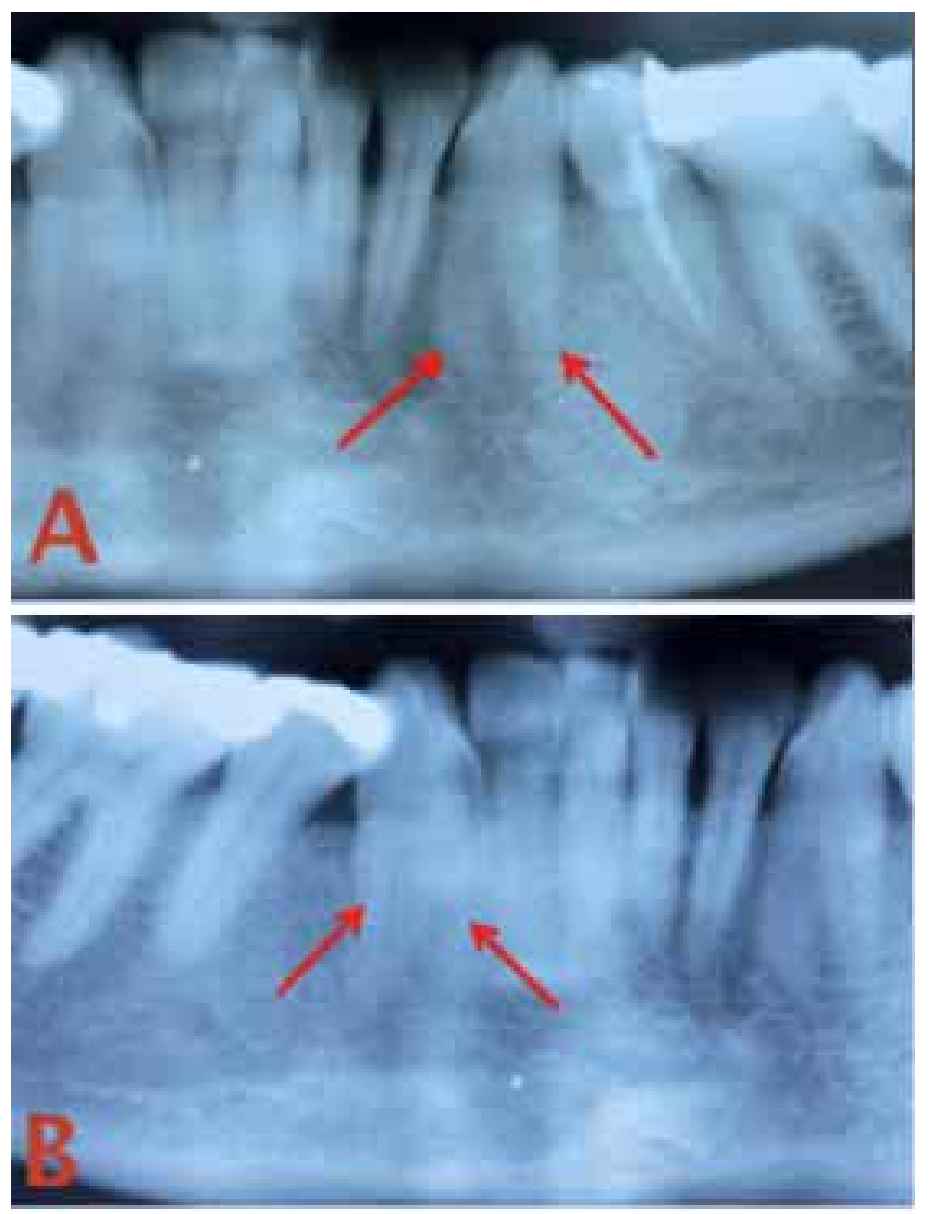

Fig. 2. Periapical radiograph of each two-rooted mandibular canine. A. Tooth 34. B. Tooth 44.

\section{DISCUSSION}

The canine is called the "cornerstone" of the mouth because of its location, which reflects its dual function to complement the incisors and premolars during mastication (Andrei et al.). Although mandibular canine generally have one root canal, the presence of two roots and two different canals has been reported by some authors (D'Arcangelo et al., 2001; Victorino et al., 2009). The prevalence of these anatomic variations in mandibular canines is $1 \%$ of the cases (Victorino et al.) and is higher in European population and low to nonexistent in Asians (Lee \& Scott, 2011).

The root and canal morphology may be evaluated by many techniques such as cone-beam computerized tomography (Tian et al., 2012), clinically (Marcaccini et al., 2012), radiographically (Oporto et al.), endoscopically (Aracena et al., 2012), among others. Thus, in this case the bilateral two-rooted mandibular canines were found radiographically. Although in the panoramic radiograph both two-rooted mandibular canines were clearly observed, a periapical radiograph was taken to confirm the number of canals of each individual's canines, concurring with Victorino et al. The two-rooted canines present a buccal and lingual root with their respective canals; finding that is impossible to observe because the radiograph is a two dimensional supplementary examination.

Versiani et al. (2011) evaluated the anatomy of two-rooted mandibular canines using a highresolution computed tomography, reporting that the furcation was frequently located in the middle thirds of roots (58\%). Also, it was noted that size of buccal and lingual roots was equal in $28 \%$ of the cases or with lingual roots larger than buccal (36\%) curved to mesial.

The knowledge of normal root canal anatomy and their variations is essential to minimize the possibility of occurrence of accidents during the development of dental treatments, as concluded Setzer et al. (2011). The final purpose of this case report highlights the importance of complete knowledge about the morphology of root canals and their possible variations, complementing the clinical examination with radiographic investigation, to increase the capacity of treating difficult cases during clinical approach. 
FUENTES, R. \& BORIE, E. Caninos mandibulares birradiculares bilaterales en el mismo individuo: presentación de un caso. Int. J. Odontostomat., 7(3):471-473, 2013.

RESUMEN: La anatomía normal de los dientes caninos comprende una raíz y un gran canal centrado a través de su eje, sin embargo algunos dientes canino pueden presentar dos raíces y dos canales. Así, el conocimiento de la anatomía normal de canal de la raíz y sus variaciones son esenciales para minimizar la posibilidad de accidentes durante el desarrollo de tratamientos dentales. En este informe se describe el caso de dientes caninos mandibulares con dos raíces y dos canales bilateralmente hallados radiográficamente en el mismo individuo.

PALABRAS CLAVE: morfología dental, canino mandibular, anatomía de la raíz.

\section{REFERENCES}

Andrei, O. C.; Margarit, R. \& Gheorghiu, I. M. Endodontic treatment of a mandibular canine with two roots. Rom. J. Morphol. Embryol., 52(3):923-6, 2011.

Aracena, R. D.; Betrán, V. V.; Fuentes, F. R. \& Borie, E. E. In vitro macroscopic and endoscopic analysis of three-rooted maxillary premolars and two-rooted mandibular premolars in the same individual: a case report. Int. J. Morphol., 30(1):19-24, 2012.

Basdra, E. K.; Kiokpasoglou, M. \& Stellzig, A. The Class II Division 2 craniofacial type is associated with numerous congenital tooth anomalies. Eur. J. Orthod., 22(5):529-35, 2000 .

Borie, E.; Oporto, G. \& Aracena, D. Dens Evaginatus in Hemophilic Patient: a case report. Int. J. Morphol., 28(2):375-8, 2010.

D’Arcangelo, C.; Varvara, G. \& De Fazio, P. Root canal treatment in mandibular canines with two roots: a report of two cases. Int. Endod. J., 34(4):331-4, 2001.

Fuentes, R. \& Oporto, G. Ectopic and impacted third molar in retromolar zone. A Case Report. Int. J. Morphol., 27(1):35$8,2009$.

Holtzman, L. Root canal treatment of a mandibular canine with three root canals. Case report. Int. Endod. J., 30(4):2913, 1997.

Lee, C. \& Scott, G. R. Brief communication: two-rooted lower canines-a European trait and sensitive indicator of admixture across Eurasia. Am. J. Phys. Anthropol., 146(3):481-5, 2011.

Marcaccini, A. M.; Pavanelo, A.; Nogueira, A. V.; de Souza, J. A.; Porciúncula, H. F. \& Cirelli, J. A. Morphometric study of the root anatomy in furcation área of mandibular first molars. J. Appl. Oral Sci., 20(1):71-81, 2012.

Oporto, G.; Fuentes, R. \& Soto, C. Variaciones anatómicas radiculares y sistema de canales. Int. J. Morphol., 28(3):945-50, 2010.
Ouellet, R. Mandibular permanent cuspids with two roots. J. Can. Dent. Assoc., 61(2):159-61, 1995.

Pécora, J. D.; Sousa Neto, M. D. \& Saquy, P. C. Internal anatomy, direction and number of roots and size of human mandibular canines. Braz. Dent. J. 4(1):53-7, 1993.

Setzer, F. C.; Boyer, K. R.; Jeppson, J. R.; Karabucak, B. \& Kim, S. Long-term prognosis of endodontically treated teeth: a retrospective analysis of preoperative factors in molars. J. Endod., 37(1):21-5, 2011.

Tian, Y. Y.; Guo, B.; Zhang, R.; Yu, X.; Wang, H.; Hu, T. \& Dummer, P. M. Root and canal morphology of maxillary first premolars in a Chinese subpopulation evaluated using cone-beam computarized tomography. Int. J. Endod., 45(11):996-1003, 2012.

Roig, M. \& Morelló, S. Introducción a la patología dentaria. Parte 1. Anomalías dentarias. Rev. Oper. Dent. Endod., $5: 51,2006$.

Uslu, O.; Akcam, M. O.; Evirgen, S. \& Cebeci, I. Prevalence of dental anomalies in various malocclusions. Am. J. Orthod. Dentofacial. Orthop., 135(3):328-35, 2009.

Versiani, M. A.; Pécora, J. D. \& Sousa-Neto, M. D. The anatomy of two-rooted mandibular canines determined using microcomputed tomography. Int. Endod. J., 44(7):682-7, 2011.

Victorino, F. R.; Bernardes, R. A.; Baldi, J. V.; Moraes I. G.; Bernardinelli, N.; Garcia, R. B. \& Bramante, C. M. Bilateral mandibular canines with two roots and two separate canals: case report. Braz. Dent. J., 20(1):84-6, 2009.

Correspondence to:

Ramón Fuentes Fernández

Departmento Odontología Integral

Facultad de Odontología

Universidad de la Frontera

Manuel Montt 112

Received: 28-04-2013

Temuco-CHILE Accepted: 16-09-2013

Email: ramon.fuentes@ufrontera.cl 